of basic physiology, enabling him or her to formulate an informed survival strategy that will maximize the chances for open-water survival.

The authors are eminent physiologists with extensive research backgrounds and experience in the medical aspects of survival at sea. The book is written for both laypeople and readers with a background in medicine and physiology. The terminology is thoroughly explained and facts are often vividly illustrated. For example, an average size man rowing leisurely would exhaust his carbohydrate stores in about $43 / 4$ hours, whereas his fat stores would be sufficient to keep him rowing for about $12 \frac{1}{2}$ days. The many citations of maritime disasters and detailed accounts of survival incidents continually remind the reader that understanding human physiology has practical applications and benefits. Many of the statistics presented emphasize the need to fully appreciate the complexity of survival issues. For example, $55 \%$ of open-water immersion deaths in the United Kingdom occur within about 3 meters (10 feet) of a safe refuge, and two thirds of those who die are regarded as good swimmers. These statistics do not suggest the cause of death to be from the protracted period of cooling required for hypothermia. "Rather, they are indicative of some incapacitating response that is rapid in onset and prevents individuals from swimming 3 meters to save their lives." The authors then go on to describe the initial, short-term, and long-term physiological responses to cold water immersion. After reading this section, even the most competent swimmer will appreciate the nature of cold-water-induced swimming failure and his or her own vulnerability.

Each chapter is followed by a summary highlighting salient points, practical recommendations for survival strategies (eg, "Body cooling during immersion can occur five times more quickly than it does in air at the same temperature. In no circumstances are you better off in the water than out of it."), medical care of victims, and prevention of specific problems through the use of sound safety practices and equipment.

The final part of the book addresses survival in open boats and life rafts and the many critical factors influencing survival: abandoning ship, life raft equipment, thermal insulation, protection from the elements, food and water rationing, watch keeping, crew discipline and morale, raft maintenance, signaling, leadership, and treating the illnesses and injuries of the crew. The section on search and rescue discusses the possible mech- anisms contributing to a victim's circum-rescue collapse and demise and gives medical guidelines for the initial prehospital treatment of casualties.

This book has a wealth of useful information. I strongly recommend it for all those who want to actively improve their chances for survival at sea.

Michael Jacobs, MD

Martha's Vineyard, MA, USA

\section{Adventure Without End}

Richard Bangs

Seattle, WA: The Mountaineers Books, 2001

US \$16.95, 221 pages, softcover

I loathed the read of another adventure travel narrative. But when I finally delved into Richard Bangs' latest book, I was thrilled by a poignant standout: Bangs is a fine wordsmith - much better, in fact, than some bestselling authors. His eloquent and dynamic choice of words gives the prose excitement, fluidity, and panache.

You don't have to be a world traveler or whitewater aficionado to enjoy these brief chapters. The 16 slice-ofthrill pieces are nicely distributed among 5 continents and as many sports. With a few, I longed to hear the full-length tale. The book opens with a remote descent of the Kilombero and Rufija rivers through Tanzania's most wild Selous game reserve. The climbs include Mount Adams in Washington State and Mount Kinabalu in Malaysian Borneo (no Everest-thank you!). The obtainable: biking Burgundy and sea kayaking Newfoundland. The classics: trekking Machu Pichu via the Inca Trail and Patagonia.

Bangs is no stranger to adventure travel; he was one of the founders of the genera. Bangs, along with John Yost, founded Sobek Expeditions in 1973. In 1991, Sobek merged with Mountain Travel, creating the foremost company in the business. Bangs is a veteran of more than a dozen books (many out of print) and multiple first descents of exotic rivers: Indus, Zambezi, Yangtze, BíoBø, Euphrates, Çoruh, and Watut. Bangs was lured into the dot.com world first with Mungo Park and later with MSNBC.com and Expedia.com, a travel Website for which he served as editor-at-large. These stories are taken from his postings.

Christopher Van Tilburg, MD Hood River, OR, USA 